\title{
Situācija Liepājā 1919. gada martā: Lietuvas tirdzniecības un rūpniecības ministra Jona Šimkus ziṇojums
}

\author{
Situation in Liepāja in March 1919: Report by Minister of Commerce and \\ Industry of Lithuania Jonas Šimkus
}

Dokumentu publicēšanai sagatavojuši, no lietuviešu valodas tulkojuši un komentējuši

Translation and commentaries by

Ëriks Jēkabsons, Dr. hist.

Latvijas Universitātes Vēstures un filozofijas fakultātes

Vēstures un arheoloğijas nodalas profesors

Aspazijas bulvāris 5, Rīga, LV-1050

E-pasts: eriks.jekabsons@lu.Iv

Edmunds Trumpa, Dr. philol.

Latvijas Universitātes Humanitāro zinātṇu fakultātes

Latvistikas un baltistikas nodalas asociētais profesors

Latvijas Universitātes Lituānistikas centra vadītājs

Visvalža iela 4a, Rīga, LV-1050

E-pasts: edmundas.trumpa@lu.Iv

1918. gadā visas Baltijas valstis proklamēja savu neatkarību Igaunija un Lietuva februārī, Latvija novembrī. Atškirībai laika ziṇā ir logisks izskaidrojums - Lietuva jau no 1915. gada pilnībā atradās vācu okupācijas varā, kas bija ieinteresēta zināma pretpoliska faktora pastāvēšanā, bet Igaunija vācu okupācijā nonāca tikai 1918. gada februārī, tomēr igauṇu elite paspēja proklamēt neatkarību pirms vācu karaspēka ienākšanas. Ne vienā, ne otrā valstī vācu okupācijas vara nepiel̦āva valstiskuma izveidošanos. Latvija vienīgā no visām Baltijas zemēm trīs gadus atradās tiešas karadarbības zonā, kurā nekāda plašāka sabiedriski politiska darbība, ieskaitot neatkarības proklamēšanu jebkādā formā pirms kara nobeiguma, nebija iespējama. Pēc kara beigām Rietumu frontē 1918. gada 11. novembrī stāvoklis krasi mainījās arī vācu karaspēka ieņemtajās teritorijās austrumos. Darbību sāka Lietuvas un Igaunijas nacionālā valdība, ko okupācijas varas iestādes pirms tam nepiel̦āva. 18. novembrī Rīgā proklamēja Latvijas Republiku, taču tās Pagaidu valdībai vēl bija jāizcīna vairāk nekā pusotru gadu ilga sarežgîita militāra un politiska cīṇa par valsts neatkarību un starptautisku atzī̌sanu. 1918.-1920. gadā Latvijas teritorijā sadūrās un visdažādākajās formās savstarpēji savijās topošās Latvijas 
Republikas, Padomju Krievijas un latviešu lielinieku (boḷševiku), vācbaltiešu, karā sakautās, pazemotās Vācijas, pretboḷ̌ševistiskās Krievijas, jauno un atjaunoto kaimiņvalstu Igaunijas, Lietuvas, Polijas, Somijas - un Rietumu lielvalstu intereses. Faktiski iekšējā un ārējā situācija tieši Latvijā 1919. gada pirmajos mēnešos bija sarežḡîtākā no Baltijas valstīm - Igaunijai izdevās atbrīvot savu teritoriju pirmajai, zināmā mērā stabilāks bija arī Lietuvas valdības stāvoklis.

1919. gada sākumā Latvijas Pagaidu valdība bija spiesta atstāt Rīgu, kuru ieñēma Sarkanā armija un kura uz vairākiem mēnešiem kḷuva par Padomju Latvijas galvaspilsētu. Valdība, kas šajā situācijā bija spiesta sadarboties ar vācu okupācijas spēkiem un vācbaltiešiem, atkāpās uz Liepāju, kur iespēju robežās turpināja darbību, cenšoties nostiprināt savu varu. Taču tam traucēja gan popularitātes trūkums, gan vācu okupācijas iestāžu neieinteresētība nodot varu Latvijas valdībai, kuras orientēšanās uz Rietumu lielvalstīm un iekšpolitiskie plāni attiecībā uz zemes reformu ne tām, ne vācbaltiešu elitei nevarēja izraisīt simpātijas. ${ }^{1}$

Jau no 1918. gada nogales Latvijas valdība īpašu vērību pievērsa tieši Lietuvai, to apliecina arī pirmā un pagaidām vienīgā pilntiesīgā diplomātiskā pārstāvja iecelšana Lietuvas galvaspilsētā Viḷnā - decembrī par Latvijas valdības pārstāvi Lietuvā kḷuva Vilis Bandrevičs (viņš pat ieradās Viḷnā, taču amatā nepaspēja stāties, jo tuvojās Sarkanā armija un Lietuvas valdība bēga no pilsētas, tāpēc 28. decembrī vinšs atgriezās Rīgā). ${ }^{2} 1919$. gada sākumā valdība centās nodibināt sakarus ar ārvalstīm - gan Parīzes miera konferencē, kur darbojās Latvijas un pārējo Baltijas valstu neoficiālas delegācijas, gan Rietumvalstu un kaimiņvalstu galvaspilsētās, uz kurieni devās Latvijas valstsvīri. Piemēram, 1919. gada februārī Ministru prezidents Kārlis Ulmanis un finanšu ministrs Spricis Paegle Stokholmā apspriedās ar Lietuvas valsts Padomes prezidentu Antanu Smetonu (Antanas Smetona) un finanšu ministru Martīnu Iču (Martynas Yčas), bet 28. februārī un 1. martā K. Ulmanis viesojās Kauñā, kur pēc sarunām parakstīja divus līgumus. Pirmais tika noslēgts ar Lietuvas Tirdzniecības un rūpniecības banku, un saskaņā ar to Latvijas valdība ieguva tiesības saņemt piecus miljonus Vācijas marku lielu aizdevumu uz vienu gadu no 100 miljoniem marku, ko Lietuvai 1918. gada beigās bija aizdevusi Vācija. Otrā līgumā Lietuvas valdība garantēja aizdevumu, iegūstot tiesības izmantot savām vajadzībām Liepājas ostu, kā arī novietot Liepājā kravu apsardzībai karaspēka nodaḷu. Turklāt puses apṇēmās sadarboties cīṇā pret Sarkano armiju. Ievērojot Latvijas Pagaidu valdības sarežgiito situāciju, šī palīdzība bija ārkārtīgi būtiska un l̦āva nodrošināt valdības iestāžu darbību. Arī Lietuvai vienošanās bija l,oti svarīga, jo vēl 7. maijā Lietuvas valdība konstatēja, ka "90\% Lietuvas tirdzniecības" iet caur Liepājas ostu (tās nonākšana boḷ̌̌eviku varā ietekmētu Lietuvu arī stratēgóiski). ${ }^{3}$

Burtiski nedēḷu pēc minēto līgumu parakstǐšanas Liepājā no Kauṇas cauri Austrumprūsijai (no Klaipēdas līdz Latvijas robežai - preču vagonā) ieradās plaša Lietuvas delegācija ar tirdzniecības un rūpniecības ministru Jonu Šimku (Jonas Šimkus, 1873-1944) priekšgalā. Tajā ietilpa arī pulkvežleitnants Mīkols Gedgauds (Mykolas Gedgaudas) no Apsardzības ministrijas (ar adjutantu Biḷūnu), inženieris Tads Šulcs (Tadas Šulcas) no Satiksmes ministrijas, ierēdnis Kruks no J. Šimkus vadītās ministrijas un agronoms Mīkols Baženskis (Mykolas Baženskis) no Pārtikas ministrijas, kā arī delegācijas sekretārs Rabinovičs. Vispārīgais uzdevums bija uz vietas noskaidrot informāciju par sadarbības iespējām, kā arī par Liepājas ostas izmantošanas organizāciju. 7. martā plkst. 13 delegāciju pieṇēma Ministru prezidents K. Ulmanis, pēc tam attiecīgo jomu pārstāvji runāja ar Latvijas amatpersonām. 
Prese īpaši uzsvēra, ka "daži no delegācijas locekḷiem runā arī latviski”" (vairāki bija dzīvojuši un mācījušies Latvijā - E. J.). 10. martā Latvijas valdības laikrakstā "Latvijas Sargs" tika publicēta plaša iepriekšējās dienas intervija ar J. Šimku, kurā viņš detalizēti aplūkoja Lietuvas situāciju, abu valstu attiecību nepieciešamību un perspektīvas, kā arī atzina, ka sarunā ar K. Ulmani īpaši interesējies par Latvijas valdības attiecībām ar Vācijas varas iestādēm Liepājā. ${ }^{5}$ Tāpat latviešu prese atzīmēja, ka sarunās abas puses guvušas "to labāko iespaidu", lietuvieši ierosinājuši arī pasta satiksmes nodibināšanu, un apspriests jautājums par drīzu diplomātisko pārstāvju apmaiṇu Liepājā un Kauñā. ${ }^{6}$

1919. gada jūlijā J. Šimkus automašīnā atkal ieradās Latvijā (viņš̌ Liepāju bija apmeklējis vairākas reizes arī Andrieva Niedras valdības varas laikā aprīlī-jūnijā, taču neveidoja ar to nekādus kontaktus, ko pats sevišksi uzsvēra), un latviešu prese īpaši atzīmēja, ka "šis Lietavas valstsvīrs bija pirmais, kas stājās tiešos sakaros ar Latvijas valdību Liepājā un atradās pirmās lietaviešu delegācijas priekšgalā, kura Liepāju apmeklēja marta sākumā". ${ }^{7}$

Publicējam J. Šimkus 1919. gada 9. martā rakstīto pārskata ziņojumu savai valdībai, kurā viņš dažas dienas pēc ierašanās samērā detalizēti apkopoja paša un citu delegācijas locekḷu iegūtās ziņas par vispārējo Latvijas politisko, militāro un sociālo situāciju. Tā kā Latvijas vēstures avotu klāsts par aplūkojamo periodu Liepājā nav liels, bet attiecību vēsturē ar Lietuvu par šo, faktiski pirmo, ārvalstu delegācijas vizīti Latvijā līdz šim nav zināms nekas, avots ir l̦oti nozīmīgs. Tajā sniegto informāciju ieguva Lietuvas delegācijas pārstāvji, un ne vienmēr tā ir precīza, taču J. Šimkus centās pēc iespējas objektīvi atspoguḷot situāciju, kādu redzēja Liepājā. Publikācijā sniegts dokuments oriǵinālvalodā (no Lietuvas Valsts arhīva Ārlietu ministrijas fonda) un dokumenta tulkojums, kas papildināts ar komentāriem.

\section{Dokumentas}

Prekybos ir Pramonès

Ministerija

9/III-19

Ponui Ministerių Kabineto Pirmininkui

Liepojus

Šimkaus bylon

Šiuomi turiu garbes pranešti Tamstai apie atliktus darbus mano komisijos Liepojuje.

Komisija Liepojun atvyko vos tik petnyčioje $7 /$ III šeštoje valandoje ryto; dviliktoje valandoje ta pačia diena komisija persistate Latvijos Ministerių Pirmininkui p. Ulmaniui, su kuriuo nutarta duot galemybes atskirių sričių atstovams susitikt su atstovais Latvijos delei pasitarimų. Pasitarime karininko Gedgaudo su Latvijos krašto apsaugos ministeriu \{civiliniu juristu Salit\} ir štabo viršininku \{kapitonu Plensneru\} surinktos sekančios žinios: prieš pasitraukiant iš Rigos Latvijos valdžia gruodzio menesyje pradejo tvert kariuomene iš savanoriu, persikelus ị Liepojų valdžia apskelbe priverstina mobilizacija kareivių tarpe 18-33 metų amžiaus ir karininkų lig i $45 \mathrm{~m}$. Dabartiniame momente kariuomene susideda iš penkių kuopų ir vieno eskadrono (išviso apie 1000 vyrų su atsarga) ant fronto ir iš vieno lavinamo bataljono atsargoje (apie 600 vyrų) Liepojuje, ị kurị ịplaukia mobilizuojami. Tam tikrų mokiklų nera, artilerijos nera, yra dvi vokiškos patrankos. Pažimetina, kad toje neskaitlingoje kariumeneje dalivauja ape 500 karininkų iš kuriu ant fronto yra sutverta 
viena atskira kuopa iš 80 asmenų. Podraug su šiuo latvių kariuomene organizuojas ir kariuomene iš vietinių vokiečių \{(jų skaičius apie 4000)\} biurgerių ir baronų iniciativa vietinių vokiškų dvarininkų; atskiros kuopos šitos kariuomenes nešioja vardus vietinių dvarininkų ir susideda, paviždžiui kuopoje kunigaikščio Liveno, iš ịvairių tautų, kurių tarpe yra rusai ir lietuviai, patekusiejie kaipo savanoriai; 13 lietuvių vieno eskadrono nor grižt Lietuvon; apart dvejų minetu kariuomenių Latvijoje veikia dar ir vokiečių freiwilligiai iš Vokietijos \{(jų skaičius Latvijoje apie 14000)\}. Frontas nuo bolševikų eina nuo juros šiauriu Vindavos 30 verstų paupiu Vindavos ant miesto Piltino, Goldingos, Vormeno, Frauenburgo, nuo kurio pasisuka ant Paupelu ir paupiu Vindavos lig Lietuvos rubežiui; iš pažimetų vietų Frauenburgas dar rankose bolševikų. Nuo Vindavos lig ị Vormeno veikia vietinių vokečių kariuomene (Landwehras), nuo Vormeno lig i Pampelnui - latvių ir toliaus germanai. Operativiniu vadu viso fronto yra vadas 6-to vokiečių-freiwilligiu korpuso generolas grafas Goltz, kuris vienija veikimą trijų atskirų kariuomenių, turinčių atskirus savo operativinius štabus. Latviai ginklų iš vokečių gavo mažai, dali didesnę gavo iš anglų, jųjų tarpe 50 šautuvų-kulkosvaidžių. Kulkosvaidžių latviai visai netur ir abelnai jaučias ginklų stoka; usisakyta ir manoma gaut iš anglų. Landweras vietinių vokečių apginkluotas pakankamai, jie tur ir kelias batarejas artilerijos, ginkluoja jos be kliučiu germanai freiwilligiai. Latvių kariuomene rubų tur dar neužtenkamai, o tie kurie tur deveja vokiškus. Kariuomene yra maitinama Latvių valdžios maistu gaunamu rekvizicijos keliu. Visoje Latvijoje karo stovis, rajonas Liepojaus visas kolei kas nemobilizuotas. Laiku paskutinios ofensivos prieš bolševikus latviai ir freiwilligiai nustoję rišių pripuolamai užpole vienį ant kitų rokuojant per apsirikimą bolševikais ir delei to nesusipratimo žuvo vadas latvių veikiančios ant fronto kariuomenes kapitonas Kalpokas su trimis aficeriais ir keletu freiwilligių. Kalpoko žuvimas padare didelị latviams nuostolį, nes tai buvo ižimiausias karininkas.

Iš pasitarimų agronomo p. Boženskio su viršininku latvių rekvizicijines komisijos p. Bliumbergu ape kariuomenes ir piliečių maitinimą surinktos šios žinios. Latvijos dvaldi ir miškai nesuliginamai geresneme stovije negu Lietuvoje, miškai buvo ekspolatojami pagal tikslaus miškų ūkio; jujų plotai užema trečdalį viso Kuršo ir remdamies savo miškais latvių atstovai Londone tikias net ant mišku gaut paskola. Baronų dvaruose germanai paliko kai kur net savaji turtą, kaip antai veisles arklius etc. Jei kur truko Kuršeje duonos, tai buvo vežama iš Lietuvos ir Šiaulių apskričio pašalinimui stokos. Freiwilligų kariuomene duona gauna iš Voketijos kitus gi produktus iš latvių valdžios už piningus. Veikia rekvizicijines Latvių komisijos, kurios nustatitomis kainomis, žemesnemis negu Lietuvoje, superka javus \{ir maistą apmokedamos rekvizicijų kvitais. Maitinimo klausimas sunkus ir maisto užteks ne daugiaus kaip vienam menesiui, nes maisto truksta kaip mieste teip ir pas kaimų gyventojus. Užsakyta Anglijoje Latvijai 50.000 tonų duonos ir 2.000 tonų riebalų, yra viltis už menesio gaut dalị užsakito.

Prekybos ir pramones atstovas Krukas surinko šias žinias.

Priekių del išvežimo iš Latvijos nera nei jokių, Liepojuje aukštomis kainomis reikalingi gyvenimui daiktai gaunami. I Liepojaus uostą labai retai atviksta laivai su priekemis, neseniai vienas laivas iš Švedijos Liepojaus uoste iškrauste 800 dežų su separatoriais kurių dalị galema pirkt (separatoriai turejo but iškrauti Gapsale).

Švedų draugija Runeberg gavo nuo Ententos tiesą isteigt reguliariškus reisus laivais du kartu i savaite tarp Liepojaus ir Stokholmo. Šiuo momentu ant reido uosto stovi trys kariški anglų mininkai. Uostas labai geras ir jame tilpsta dideli laivai su 25 pedu 
gilio. Uoste komerciškame yra daug sandelių, kuriuos galema lengviai gaut nuomon pas jų savininkus; jie visi yra dabar tuštus. Iš Liepojaus ị Kopenhagą yra kabelis privatiškos draugijos, kuriuo galema naudotis del susinešimo. Kolai kas Liepojaus uostai prigul nie Latvijos valdžiai o miesto savivaldybai, vienog valdžia mano jos paimt savo žinion neilgai trukus.

Susisiekimo Ministerijos atstovas inžinierius Šulcas pasitaręs su Latvijos Susisiekimo Ministeriu p. Hermanovskiu, kursai pildo pareigas \{ir\} ministerio prekybos ir pramones, surinko sekančias žinias. Užimtoje bolševiku puseje, rajone Valk-Riga-Daugpilis Latvijos valdžia dar prieš ateinant bolševikams iš vokečių, jiems pasitraukiant, pereme gelžkelius, du savaičiu eksploatavo kol jų neužeme bolševikai. Šiapus sienos visi keliai yra rankose vokečių ir latvių valdžia negal nustatyt laiko, kuomet pati valdyt prades. Prieš musų norą ateityje turet galemybe savo traukiniais pasiekt Liepojų latviai nieko netur, tik Latvijos Susisiekimo ministerija mano, kad Latvija isikurs visur pas save rusų platumo gelžkelị (jujų ekonomiški rišiai linkstą Rusios pusen daugiau negu kur kitur) ir tuomet negaledama naudotis musų keliu nuo Mažeikių lig Liepojaus tures isiteisyt \{paraleliškai\} savaji rusiškaji nuo Ringeno lig i Liepojaus, nes ne gal atsisakyt nuo palaikimo rišių tarp Rigos ir Liepojaus; atiduot kelių nuo Ventos lig ị Liepojaus musų vienų žinion latviai matyt ne mano. Gelžkelių dirbtuves Liepojuje ir laivų dirbtuves uoste akvačiai suteiktų mums pagelbos, kilus reikalui. Uostas su šleperiais ir visais kranais ir prietaisomis kolai kas prigul miesto savivaldybei, greitu laiku bus perimti Latvijos valdžios ir kilus reikalui Lietuvai naudotis bus suteikta galemybe; mažų laivų musų Nemuno reikalams nusipirkt če negalema. Latvijos Krasų Valdyba noret užmegzt su musų Krasų rišius, kad siuntinet korrespondencija ir kitus siuntinius \{Lietuvon\}. Kuomet atsiras faktiška galemybe siuntinet traukinius betarpiai iš Kauno ị Liepojų, reikes komisijoms latvių ir lietuvių tartis galutinai tarp saves ir vokiečiais delei galutinių sątikių ir nusistatimo mišrosę vietose ir pasirašyt po nutarimu atstovams. Latvių valdžia perimdama iš vokečių valdžios Liepojaus gelžkelių dirbtuves, pereme podraug 12 sugedusių garvežių ir kelesdešims priekinių vagonų; ta visa pasitaisę latviai tures pradžiai judinamajị-riedamaji materijalą tik lieka igyt kelią, kurị kolai kas vokečiai ne duoda ir nors eksploatuot patis karo siekiams.

Pereidamas prie bendro politiško stovio Latvijos turiu pranešti štai ką.

Latvijos laikinoji valdžia pasiremia ant turtingesnių latvių krašto gyventojų, jujų skaičius visgi yra mažumoje, nes net mažumiečiai valdžiai neužtiki, nekalbant jau apie didžiumiečius, kurių skaičius Liepojaus miesto savivaldyboje sutvere puse t. yra 40 asmenų iš 80 narių skaičiaus. Vokečiai biurgieriai turedami savo rankose visa prekyba ir pramone, nesutikdami su politika, kurią varo laikinoji Latvių valdžia, visgi jają pripažinsta ir palaiko ir net yra griežtai nusistatę prieš germanų politika Latvijoje. Vietiniai vokečiai dvarininkai savo simpatijoms linksta prie germanų ir tik baime už savo dvarus verčia jos kovot draugeje su latviais prieš didžiumiečius. Jie tur kariumene ir didesne ir geriau apginkluotą negu latvių kariumene ir šiuo momentu sunku permatyt kaip toji kariuomene bus sunaudota, pasibaigus kovai su bolševikais. Latvių valdžia yra dar pradedamoje fasoje organizacijos ir labai silpnai pildo \{darba\} daugalyje skyriuose ukio.

Dieną ankščiaus negu mes ị Liepojų atviko anglų komisija iš trijų narių delei ištirimo Latvijos stovio. Subatoje 8/III aš buvau priimtas komisijoje, kuriai įteikiau memoriala su parašu Ministerių Pirmininko ir du pranešimu su savo parašu apie dabartini stovi daliku Lietuvoje. Mano pasikalbejimas tęses 3 valandas. Komisija labai įdomavo organizacija valdžios Lietuvoje, ekonomišku padejimu krašto, organizacija kariuomenes ir frontu prieš 
bolševikus. Komisijos pirmininkas majoras Kenanas žadejo iš laivo per radio pranešt ape pasikalbejimą su manimi į Londoną o popierius išsiust laivu.

I mano pakvietima atvikt Kaunan akvačiai sutiko, pranešdamas, jog nevažiuosiąs pas mus per Voketija, todel pažadejau ji pasiimt už dvejų savaičių musų automobiliu ant ko jis sutiko. Panedelyje 10/III 10 valandoje ryto turiu komisijoje audiencija kartu su karininku Gedgaudu. Noriu gaut tiesa per komisija susinešt su Londonu ir gaut tiesa per Liepojaus uostą vardu Lietuvos valdžios atvežt maistą ir kitas priekes. Iš Liepojaus išvažiuosiu ketvirtadienyje 13/III 5 valandoje ryto. Klaipedoje susituresiu vienai dienai susipažint su uostu. Apsistosiu Hotele Unione.

Kiti nariai komisijos Šulcas, Gedgaudas ir Krukas četverge arba petnyčioje važiuos i Reveli ir Gelsingforsą.

Su pagarba Jonas Šimkus

\section{Dokuments}

Tirdzniecības un rūpniecības ministrija

9.III.1919

Liepāja

Ministru kabineta priekšsēdētāja kungam ${ }^{8}$

Uz Šimkus ${ }^{9}$ lietu

Ar šo man ir gods paziņot Jums par darbiem, kurus mana komisija veikusi Liepājā.

Komisija uz Liepāju atbrauca tikai piektdien, 7.III, plkst. sešos no rīta; tajā pašā dienā plkst. divpadsmitos komisija stādījās priekšā Latvijas Ministru prezidentam Ulmaņa ${ }^{10}$ k-gam, ar kuru panākta vienošanās dot iespēju atsevišku jomu pārstāvjiem tikties pārrunās ar Latvijas pārstāvjiem. Virsnieka Gedgauda ${ }^{11}$ sarunās ar Latvijas apsardzības ministru (civilo juristu Zālīti ${ }^{12}$ ) un štāba priekšnieku (kapteini Plensneru ${ }^{13}$ ) apkopotas šādas ziņas: pirms atkāpšanās no Rīgas Latvijas valdība decembrī sākusi veidot karaspēku no brīvprātīgajiem, pēc pārcelšanās uz Liepāju valdība izsludinājusi piespiedu mobilizāciju kareivjiem 18-33 gadu vecumā un virsniekiem līdz 45 g[adu] v[ecumam]. Pašlaik karaspēks sastāv no piecām rotām un viena eskadrona frontē (kopā ap 1000 vīru ar rezervi) un no viena mācību bataljona rezervē (ap 600 vīru) Liepājā, kur nokḷūst mobilizējamie. ${ }^{14}$ Konkrētu [kara] skolu nav, artilērijas nav, ir divi vācu lielgabali. Jāatzīmē, ka šajā skaita ziņā nelielajā karaspēkā ir apmēram 500 virsnieku, no kuriem frontē ir izveidota viena atsevišķa rota no 80 vīriem. Līdz ar latviešu karaspēku organizējas arī karaspēks no vietējiem vāciešiem (to skaits ap 4000) - birǵgeriem ${ }^{15}$ un baroniem - pēc vietējo vācu muižnieku iniciatīvas; atsevišķas šì karaspēka rotas tiek dēvētas vietējo muižnieku vārdos, un pastāv, piemēram, kṇaza Līvena ${ }^{16}$ rota, tajā ir dažādu tautu pārstāvji, starp viniiem ir krievi un lietuvieši, kas iestājušies kā brīvprātīgie; 13 lietuvieši no viena eskadrona vēlas atgriezties Lietuvā; bez diviem minētajiem karaspēkiem Latvijā darbojas vēl arī vācu brīvprātīgie algotņi [Freiwillige] no Vācijas (to skaits Latvijā ir ap 14 000). Boḷ̌seviku fronte iet no jūras uz ziemel̦iem no Ventspils 30 verstu gar Ventas krastu uz Pilteni, Kuldīgu, Vārmi, Saldu, no kurienes pagriežas uz Pampāliem un pa Ventas krastu iet līdz Lietuvas robežai; no atzīmētajām vietām Saldus vēl ir boḷ̌̌eviku rokās. No Ventspils līdz Vārmei atrodas vietējo vāciešu karaspēks (Landeswehr), no Vārmes līdz Pampāḷiem - latviešu [karaspēks] un tālāk vācieši. Visas frontes operatīvais virspavēlnieks ir 6. vācu-brīvprātīgo 
algotņu korpusa ${ }^{17}$ komandieris ǵenerālis grāfs Golcs, ${ }^{18}$ kura vadībai pakḷaujas trīs atsevišḳi karaspēki, no kuriem katram ir savs atseviškss operatīvais štābs. Latvieši no vāciešiem ir saņēmuši maz ieroču, lielāko daḷu tie dabūjuši no angḷiem, ieskaitot 50 patšautenes. Ložmetēju latviešiem nemaz nav, un vispār ir jūtams ieroču trūkums; tie ir pasūtīti un, domājams, tiks saṇemti no angḷiem. Vietējo vāciešu landesvērs ir apbruṇots pietiekami, viņiem ir vairākas artilērijas baterijas, viņus bez kavēšanās apbruṇo vācu brīvprātīgie algotņi. Latviešu karaspēkam vēl trūkst apgêerba, bet tie [karavīì], kuriem tas ir, valkā vācu formas. Karaspēks tiek barots ar latviešu valdības pārtiku, kas tiek iegūta rekvizīcijās. Visā Latvijā ir karastāvoklis, viss Liepājas rajons pagaidām nav mobilizēts. Pēdējā uzbrukumā bol̦ševikiem latvieši un brīvprātīgie algotṇi, zaudējot sakarus, nejauši uzbrukuši cits citam, kḷūdaini noturot otru pusi par boḷševikiem, un šī pārpratuma dēḷ gājis bojā frontē esošais latviešu karaspēka komandieris kapteinis Kalpaks ${ }^{19}$ ar trijiem virsniekiem un vairākiem brīvprātīgajiem algotn,iem. ${ }^{20}$ Kalpaka bojāeja nodarījusi latviešiem lielu zaudējumu, jo viņš bijis visievērojamākais virsnieks.

No agronoma Boženska ${ }^{21}$ k-ga pārrunām ar latviešu rekvizīcijas komisijas priekšnieku Blumberga ${ }^{22}$ k-gu par karaspēka un pilsoṇu ēdināšanu savāktas šādas ziņas. Latvijas muižas un meži ir nesalīdzināmi labākā stāvoklī nekā Lietuvā, meži tika izmantoti saskaņā ar precīziem mežu apsaimniekošanas principiem; to platība aizṇem trešo dalu visas Kurzemes, ${ }^{23}$ un, balstoties uz savām [lielajām] mežu platībām, latviešu pārstāvji Londonā pat cer pret mežiem saņemt aizdevumu. Baronu muižās vācieši dažviet atstājuši arī savu īpašumu, proti, vaislas zirgus utt. Ja kaut kur Kurzemē nebijis maizes, tad trūkuma novēršanai tā tika vesta no Lietuvas un Šauḷu apriṇka. Brīvprātīgo algotṇu karaspēks maizi saṇem no Vācijas, savukārt citus produktus - no latviešu valdības par naudu. Darbojas latviešu rekvizīcijas komisijas, kas saskaṇā ar noteiktajām cenām, kuras ir zemākas nekā Lietuvā, iepērk labību (un pārtiku), maksājot par to ar rekvizīciju kvītīm. Ėdināšanas jautājums ir smags, un pārtikas pietiks ne vairāk kā vienam mēnesim, jo pārtikas trūkst kā pilsētā, tā arī lauku iedzìvotājiem. Anglijā Latvijai ir pasūtīti 50000 tonnu maizes un 2000 tonnu tauku, ir cerība pēc mēneša saṇemt daḷu pasūtījuma.

Tirdzniecības un rūpniecības pārstāvis Kruks ${ }^{24}$ ir savācis šādas ziņas.

No Latvijas nav paredzēts izvest nekādas preces, Liepājā dzīvošanai nepieciešamās lietas par augstām cenām ir dabūjamas. Liepājas ostā ḷoti reti iebrauc kug̣i ar precēm, nesen viens kugíis no Zviedrijas Liepājas ostā izkrāva 800 kastes ar separatoriem, ${ }^{25}$ daḷ no tiem iespējams nopirkt (separatori bija jāizkrauj Hāpsalā).

Zviedru sabiedrība Runeberg ${ }^{26}$ ir saṇēmusi no Antantes tiesības nodibināt regulāros reisus ar kug̣iem divreiz nedēḷā starp Liepāju un Stokholmu. Pašlaik ostas reidā stāv trīs angḷu mīnu karakug̣i. ${ }^{27}$ Osta ir l, loti laba, un tajā var ienākt lieli kuği ar 25 pēdu iegrimi. Tirdzniecības ostā ir daudz noliktavu, kuras var viegli izīrēt no to īpašniekiem; tās visas pašlaik ir tukšas. No Liepājas uz Kopenhāgenu ievilkts privātas sabiedrības [telegrāfa] kabelis, kuru var izmantot sakariem..$^{28}$ Pagaidām Liepājas ostas pieder nevis Latvijas valdībai, bet pilsētas pašvaldībai, tomēr valdība domā drīz vien tās pārṇemt savā pārziṇā.

Satiksmes ministrijas pārstāvis inženieris Šulcs, ${ }^{29}$ apspriežoties ar Latvijas satiksmes ministru Hermanovska ${ }^{30}$ k-gu, kurš pilda (arī) tirdzniecības un rūpniecības ministra pienākumus, ir savācis šādas ziṇas. Boḷševiku ien̦emtajā daḷā Valkas-Rīgas-Daugavpils rajonā Latvijas valdība vēl pirms boḷševiku ienākšanas no vāciešiem, viṇiem atkāpjoties, ir pārn,ēmusi dzelzceḷus un divas nedēḷas tos ekspluatējusi, kamēr neienāca boḷševiki. Šaipus robežas visi ceḷi ir vācu rokās, un latviešu valdība nevar pateikt, kad pati tos pārṇems. 
Pret mūsu vēlmi nākotnē īstenot iespēju nodibināt savu vilcienu satiksmi ar Liepāju latvieši kategoriski neiebilst, vienīgi Latvijas Satiksmes ministrija uzskata, ka Latvija visur ierīkos dzelzceḷu ar krievu [lietotā] platuma [sliedēm] (viṇu ekonomiskie sakari sliecas uz Krievijas pusi vairāk nekā citur), un tad, nevarēdama izmantot mūsu ceḷu no Mažeikiiem līdz Liepājai, būs spiesta ierīkot (paralēli) savu krievisko [dzelzceḷu] no Reņgées līdz Liepājai, jo nevar atteikties no sakaru uzturēšanas starp Rīgu un Liepāju; atdot ceḷus no Ventas līdz Liepājai vienīgi mūsu uzraudzībā latvieši, šḳiet, negrasās. Ar dzelzceḷa darbnīcu Liepājā un kug̣u remonta darbnīcu ostā [viṇi] labprāt sniegtu mums palīdzību, ja rastos vajadzība. Osta ar velkoṇiem un visiem ceḷamkrāniem un iekārtām pagaidām pieder pilsētas pašvaldībai, tuvākā laikā tos pārṇems Latvijas valdība, un nepieciešamības gadījumā Lietuva varēs tos izmantot; mazos kuğus mūsu Nemunas vajadzībām nopirkt šeit nevar. Latvijas Pasta [un telegrāfa] pārvalde gribētu nodibināt sakarus ar mūsu Pastu, lai varētu nosūtìt korespondenci un citus sūtījumus (uz Lietuvu). Kad radīsies reāla iespēja nosūtīt vilcienus tieši no Kaunas uz Liepāju, latviešu un lietuviešu komisijām savā starpā un ar vāciešiem vajadzēs līdz galam vienoties par pēdējiem jautājumiem un nostāju strīdīgajos punktos un vienošanos parakstīt [abu pušu] pārstāvjiem. Latviešu valdība, pārṇemdama no vācu valdes Liepājas dzelzceḷu darbnīcas, pārṇēmusi arī 12 bojātas tvaika lokomotīves un vairākus desmitus preču vagonu; visu to salabojot, latviešiem sākumā būs kustošaisritošais [dzelzceḷa] sastāvs, atliek tikai iegūt dzelzceḷu, kuru vācieši pagaidām neatdod un vēlas ekspluatēt paši militārām vajadzībām.

Pārejot pie vispārējā Latvijas politiskā stāvokḷa, man ir jāpaziṇo, lūk, kas.

Latvijas Pagaidu valdība balstās uz turīgākajiem latviešu iedzīvotājiem, tomēr to ir mazākums, jo pat sīkzemnieki valdībai neuzticas, nerunājot jau par lieliniekiem, kuru skaits Liepājas pilsētas pašvaldībā veido pusi, t. i., 40 personas no 80 locekḷu skaita. ${ }^{31}$ Vācu birǵeri, turēdami savās rokās visu tirdzniecību un rūpniecību un nepiekrizdami politikai, kuru realizē latviešu Pagaidu valdība, tomēr to atzīst un atbalsta un pat ir stingri noskaņoti pret Vācijas politiku Latvijā. Vietējie vācu muižnieki simpatizē valstsvāciešiem, un tikai bailes par savām muižām piespiež viņus kopā ar latviešiem cīnīties pret lieliniekiem. Viṇu karaspēks ir gan lielāks, gan labāk apbruņots nekā latviešu karaspēks, un pagaidām ir grūti paredzēt, kā šis karaspēks tiks izmantots pēc cīņas beigām ar boḷ̌ševikiem. Latviešu valdība vēl atrodas organizācijas sākumstadijā un ḷoti vāji veic (darbu) daudzās saimniecības nozarēs.

Dienu agrāk nekā mēs Liepājā ieradās angḷu komisija ${ }^{32}$ trīs locekḷu sastāvā, lai izpētītu Latvijas stāvokli. Sestdien, 8.III, es tiku pieņemts komisijā, kurai iesniedzu memorandu ar [Lietuvas] Ministru prezidenta parakstu un divus ziņojumus ar savu parakstu par pašreizējo stāvokli Lietuvā. Mūsu saruna ilga 3 stundas. Komisiju l,oti interesējusi valdības organizācija Lietuvā, zemes ekonomiskais stāvoklis, karaspēka organizācija un fronte pret boḷševikiem. Komisijas priekšsēdētājs majors Kenans ${ }^{33}$ solījis no kuğa pa radio paziņot par sarunu ar mani Londonai, bet dokumentus nosūtīt ar kuĝ̣i.

Manam uzaicinājumam ierasties Kaunā [Kenans] labprāt piekrita, paziņojot, ka nebraukšot pie mums caur Vāciju, tāpēc es apsolīju viṇu pēc divām nedēḷām aizvest ar mūsu automobili, un viņš piekrita. Pirmdien, 10. III, plkst. 10 no rīta man ir pieņemšana komisijā kopā ar virsnieku Gedgaudu. Gribu saṇemt atḷauju ar komisijas starpniecību sazināties ar Londonu un atḷauju caur Liepājas ostu Lietuvas valdības vārdā atvest pārtiku un citas preces. No Liepājas izbraukšu ceturtdien, 13.III, plkst. 5 no rīta. Klaipēdā uzkavēšos vienu dienu, lai iepazìtos ar ostu. Apmetīšos viesnīcā Unione. 
Citi komisijas locekḷi, Šulcs, Gedgauds un Kruks, ceturtdien vai piektdien dosies uz Rēveli ${ }^{34}$ un Helsingforsu. ${ }^{35}$

Ar cieñu Jons Šimkus

Avots: Lietuvos Valstybinis Archyvas, 383-7-38, 1.-6. 1p. Rokraksts.

\section{ATSAUCES UN SKAIDROJUMI}

${ }^{1}$ Sīkāk par norisēm Latvijā aplūkojamajā periodā sk.: ĒRIKS JĒKABSONS, JĀNIS ŠILIN̦š (sast.). Cīṇa par brīvību: Latvijas Neatkarības karš (1918-1920) Latvijas Valsts vēstures arhīva dokumentos. 1. daḷa. 1918. gada 18. novembris - 1919. gada 16. aprīlis. Vēstures Avoti, X. Rīga 2019.

${ }^{2}$ Sk.: Latvijas Pagaidu valdības sēdes protokols, 28.12.1918. Latvijas Nacionālais arhīvs, Latvijas Valsts vēstures arhīvs, Rīga, 1313-1-1, 33. lp.

${ }^{3}$ Sīkāk par Latvijas un Lietuvas attiecībām aplūkojamajā laikā sk.: ĒRIKS JĒKABSONS. Latvijas attiecības ar Lietuvu 1919.-1921. gadā. In: Latvijas Vēsture 1997, Nr. 1, 85.-91. lpp.; Nr. 2, 25.-34. lpp.

${ }^{4}$ Sabiedroto un Lietaviešu delegācijas Liepājā. In: Latvijas Sargs, 08.03.1919., 6. lpp.

${ }^{5}$ Lietava un Latvija. In: Latvijas Sargs, 10.03.1919., 2. 1pp.

${ }^{6}$ Latviešu delegācija. In: Latvijas Sargs, 10.03.1919., 3. lpp.

${ }^{7}$ Saruna ar Lietavas tirdzniecības un rūpniecības ministru. In: Darbs, 17.07.1919., 4. lpp.

${ }^{8}$ Lietuvas valdības Ministru prezidents šajā laikā bija Mīkols Sleževičs (Mykolas Sleževičius; 1882-1939).

${ }^{9}$ Jons Šimkus (Jonas Šimkus; 1873-1944), Lietuvas kīmiḳis un valstsvīrs, mācījies ǵimnāzijā Liepājā. 1918. gada decembrī - 1919. gada 12. martā un aprīìi-oktobrī tirdzniecības un rūpniecības ministrs, 1921.-1922. gadā aizsardzības ministrs, vēlāk Kauņas Universitātes rektors. No 1924. gada arī Lietuviešu-latviešu tuvināšanās biedrības priekšsēdētājs.

${ }^{10}$ Kārlis Ulmanis (1877-1942), valstsvīrs. 1918. gada 17. novembrī - 1921. gadā Latvijas Pagaidu valdības Ministru prezidents.

${ }^{11}$ Mīkols Gedgauds (Mykolas Gedgaudas; 1885-1942), Lietuvas armijas virsnieks, pulkvežleitnants, vēlāk pulkvedis. 1919. gada janvārī-maijā Zemes apsardzības ministrijas Apgādes daḷas Artilērijas nodaļas priekšnieks, vēlāk pulka komandieris. Miris padomju ieslodzījumā.

12 Jānis Zālītis (1874-1919), advokāts, valstsvīrs. 1912.-1917. gadā Krievijas Valsts domes deputāts. 1918. gada decembrī - 1919. gada jūlijā Latvijas Pagaidu valdības apsardzības ministrs.

${ }^{13}$ Aleksandrs Plensners (1892-1984), virsnieks. 1918. gada 21. novembrī iestājās Latvijas Pagaidu valdības dienestā (kapteinis), no 11. decembra Apsardzības ministrijas Galvenā štāba G̦enerālštāba 1. nodaḷas (Organizācijas nodaḷas) priekšnieks (no 31. decembra G̣enerālštāba priekšnieka vietas izpildītājs).

${ }^{14}$ Ziṇojuma autors neierēḳina skaiț̣os Igaunijas armijas sastāvā esošās Latvijas Pagaidu valdības vienības.

${ }^{15}$ Birğeri - domāti pilsētnieki.

${ }^{16}$ Anatols fon Lĩvens (1873-1937), kṇazs (firsts), Mežotnes muižas īpašnieks, virsnieks. 1919. gada janvārī-jūnijā landesvēra krievu nodaḷas komandieris, pēc 16. aprīḷa apvērsuma atteicās no piedāvātā direktorāta locekḷa amata.

${ }^{17}$ Runa ir par Vācijas armijas 6. rezerves korpusu.

${ }^{18}$ Rīdigers fon der Golcs (Rüdiger von der Goltz; 1865-1946), Vācijas armijas virsnieks, ǵenerālmajors. Pirmā pasaules kara laikā karoja Austrumu un Rietumu frontē. 1918. gadā komandēja vācu 
ekspedīcijas karaspēku Somijā, Somijas Pilsoṇu kara dalībnieks. 1919. gada 1. februārī ieradās Liepājā, uzṇemoties Vācijas armijas 6. rezerves korpusa komandiera un Liepājas gubernatora amatu; oktobrī Vācijas valdība atsauca R. fon der Golcu no Latvijas.

${ }^{19}$ Oskars Kalpaks (arī Kolpaks; 1882-1919), virsnieks, pulkvedis, no 1918. gada decembra Pagaidu valdības brunotajos spēkos; no 31. decembra Latvijas zemessardzes visu latviešu vienību komandieris. No 1919. gada janvāra 1. latviešu atsevišḳā bataljona komandieris. Kritis 1919. gada 6. martā.

${ }^{20}$ Kopā ar O. Kalpaku krita kapteinis Nikolajs Grundmanis, virsleitnants Pēteris Krievs un piekomandētais vācu leitnants Hanss Šrēders.

${ }^{21}$ Mīkols Bažensks (Mykolas Baženskis), agronoms, no 20. gadsimta sākuma Burbišku muižas īpašnieks Radvilišķes apriņkī, pārvērta to par paraugsaimniecību.

22 Jānis Blumbergs (1886-1941), valstsvīrs. Latvijas Pagaidu valdības apgādības (pārtikas) ministra biedrs (1918-1919; 1919), arī apgādības ministrs (1919; 1919-1920).

${ }^{23}$ Domāta Kurzemes guberņa, resp., Kurzeme un Zemgale.

${ }^{24}$ Ierēdṇa Kruka (Krukas) personību pagaidām nav izdevies noskaidrot.

${ }^{25}$ Jādomā, runa ir par piena separatoriem.

${ }^{26}$ 1919. gada pirmajos mēnešos satiksmi starp Stokholmu un Liepāju uzturēja zviedru pasažieru tvaikonis Runeborg.

${ }^{27}$ Britu karakug̣i, ar kuriem ieradās arī Militārā misija, iebrauca Liepājas ostā 6. martā.

${ }^{28}$ Runa ir par Dānijas "Ziemeḷu" telegrāfa sabiedrību. Tās kabelis no Liepājas uz Kopenhāgenu 1919. gada pirmajā pusē faktiski veidoja vienīgo tiešo sakaru iespēju ar Eiropas valstīm.

${ }^{29}$ Tads Šulcs (Tadas Šulcas; 1880-1940), Lietuvas inženieris-konstruktors. Bērnību pavadījis un mācījies Liepājā, studējis Rīgas Politehniskajā institūtā. No 1918. gada Lietuvas valsts dienestā.

${ }^{30}$ Teodors Hermanovskis (1883-1964), inženieris, valstsvīrs. 1918.-1919. gadā Latvijas Pagaidu valdības satiksmes un darba ministrs. 1919. gada janvārī-februārī pildīja arī tieslietu, finanšu, tirdzniecības un rūpniecības un zemkopības ministra pienākumus.

${ }^{31}$ Runa ir nevis par boḷševikiem (lieliniekiem), bet par Latvijas Sociāldemokrātiskās strādnieku partijas biedriem.

${ }^{32}$ Runa ir par Lielbritānijas Militāro misiju Baltijas valstīs.

33 Ostins Kīnens (Austin Keenan; 1887-1957), Lielbritānijas armijas majors, no 1919. gada marta Militārās misijas Baltijas valstīs vadītājs, 1919. gada vasarā - 1920. gadā misijas vadītāja vietnieks.

${ }^{34}$ Rēvele - Tallina.

${ }^{35}$ Helsingforsa - Helsinki. 